\title{
Erratum to: The Near Islands (the Aleutian Arc): History of Vegetation in the Holocene
}

\author{
O. I. Smyshlyaeva ${ }^{a, *}$, E. E. Severova ${ }^{b}$, B. F. Khasanov ${ }^{a}$, O. A. Krylovich ${ }^{a}$, \\ E. A. Kuzmicheva ${ }^{a}$, and A. B. Savinetsky ${ }^{a}$ \\ ${ }^{a}$ Severtsov Institute of Ecology and Evolution, Russian Academy of Sciences, Moscow, 119071 Russia \\ ${ }^{b}$ Biology Faculty, Moscow State University, Moscow, 119191 Russia \\ *e-mail: smyslyaevaol@gmail.com
}

Received August 24, 2020; revised September 4, 2020; accepted November 17, 2020

DOI: $10.1134 / \mathrm{S} 1062359021660018$

The article "The Near Islands (the Aleutian Arc): History of Vegetation in the Holocene", written by O.I. Smyshlyaeva, E.E. Severova, B.F. Khasanov, O.A. Krylovich, E.A. Kuzmicheva, and A.B. Savinetsky, was originally published electronically in Springer-Link on 22 July 2021 without Open Access. After publication in volume 48, issue 4, pages 440-449 the authors decided to make the article an Open Access publication. Therefore, the copyright of the article has been changed to (C) The Author(s) 2021 and the article is forthwith distributed under the terms of a Creative Commons Attribution 4.0 International License (http://creativecommons.org/licenses/by/4.0/, CC BY), which permits use, duplication, adaptation, distribution and reproduction of a work in any medium or format, as long as you cite the original author(s) and publication source, provide a link to the Creative Commons license, and indicate if changes were made.
The original article can be found online at https://doi.org/10.1134/S1062359021040130

\section{OPEN ACCESS}

This article is licensed under a Creative Commons Attribution 4.0 International License, which permits use, sharing, adaptation, distribution and reproduction in any medium or format, as long as you give appropriate credit to the original author(s) and the source, provide a link to the Creative Commons licence, and indicate if changes were made. The images or other third party material in this article are included in the article's Creative Commons licence, unless indicated otherwise in a credit line to the material. If material is not included in the article's Creative Commons licence and your intended use is not permitted by statutory regulation or exceeds the permitted use, you will need to obtain permission directly from the copyright holder. To view a copy of this licence, visit http://creativecommons.org/licenses/by/4.0/. 